\title{
ANALISIS KONTRASTIF PANDANGAN MAHASISWA PENUTUR BAHASA INDONESIA DAN MAHASISWA PENUTUR BAHASA JEPANG TERHADAP PRIVASI DALAM KOMUNIKASI: SEBUAH TINJAUAN SOSIOLINGUISTIK
}

\author{
Sonda Sanjaya*1 ${ }^{1}$, Yuriko Ando ${ }^{2}$ \\ ${ }^{1,2}$ Program Studi Pendidikan Bahasa Jepang, Universitas Muhammadiyah Yogyakarta, \\ Jl. Lingkar Selatan, Kasihan, Bantul, Yogyakarta 55183, Indonesia \\ *e-mail: sonda.van.sanjaya@gmail.com \\ phone: +62-853-1895-2232
}

\begin{abstract}
Abstrak
Perbedaan pandangan di antara mahasiswa penutur bahasa Indonesia dan mahasiswa penutur bahasa Jepang terhadap privasi dalam komunikasi memungkinkan menyebabkan terjadinya gangguan dalam proses berkomunikasi dan mengundang kesalahpahaman. Guna mengurangi gangguan komunikasi dan kesalahpamahan, maka kajian penelitian mengenai privasi dalam komunikasi sangat diperlukan. Penelitian ini mengkaji persamaan dan perbedaan ranah privasi mahasiswa penutur bahasa Indonesia dan mahasiswa penutur bahasa Jepang, siapa saja yang boleh dan tidak boleh mengetahui privasi penutur, dan bagaimana respons penutur terhadap mitra tutur yang membahas topik pembicaraan yang berkaitan dengan privasi.

Penelitian ini dilakukan dengan analisis kontrastif dan teknik survey dengan mendistribusi kuesioner kepada 127 responden di Indonesia dan 107 responden di Jepang. Responden di Indonesia adalah mahasiswa penutur asli bahasa Indonesia dan responden di Jepang adalah mahasiswa mahasiswa penutur asli bahasa Jepang di Jepang.

Hasil penelitian menunjukkan bahwa mahasiswa penutur bahasa Indonesia lebih terbuka terhadap privasi dibandingkan dengan mahasiswa penutur bahasa Jepang. Kemudian, mahasiswa penutur bahasa Jepang membicarakan privasi terhadap mitra tutur sembari mempertimbangkan apakah penutur dan mitra tutur memiliki hubungan kepercayaan atau tidak. Sedangkan mahasiswa penutur bahasa Indonesia memutuskan akan membicarakan hal yang berkaitan dengan privasi atau tidak dengan mitra tutur setelah memastikan apakah ada hubungan kepercayaan atau tidak.
\end{abstract}

Kata kunci : privasi; komunikasi; analisis kontrastif; sosiolinguistik

\begin{abstract}
The different perspectives on privacy between college students who speak Indonesian and those who speak Japanese as their native language may create some misunderstandings when they interact with each other. To avoid such misunderstandings, more studies on privacy in communication are needed. Meanwhile studies on the field are still scarce. Therefore, to fill the gap, this study aims at finding out the similarities and differences on topics that are considered as privacy by students who speak Indonesian language and Japanese language. Additionally, this study also revealed to which interlocutors they may be comfortable to open up talking about topics considered as their privacy and how they respond towards interlocutors who bring up such topics.
\end{abstract}


To collect the data, a questionnaire on privacy was distributed to 127 participants in Indonesia and 107 participants in Japan. Respondents from both countries were college students who were native speakers of the language spoken in their countries, Japan and Indonesia. The data collected then were analyzed by employing contrastive analysis.

The study indicated that Indonesian students were more open in comparison to Japanese students as indicated by the breadth of their preferred conversation topics with strangers. Additionally, when opening up to topics considered as private topics, Japanese students were simultaneously evaluating whether they had trusted relationship with the interlocutors throughout the interaction. On the other hand, instead of simultaneously evaluating the relationship, Indonesian students tended to decide whether they had the trusted relationship first before they proceeded to opening up about their privacy with their interlocutors.

\section{Keywords: privacy, communication, contrastive analysis, sociolinguistics}

\section{Pendahuluan}

Indonesia dan Jepang berada pada wilayah Asia, namun latar belakang budaya, sejarah, pola pikir yang terdapat di kedua negara sangat berbeda.

Perbedaan tersebut seringkali menyebabkan kesalahpahaman di antara dua bangsa tersebut. Masyarakat Indonesia memiliki karakter terbuka, mudah akrab dengan orang yang baru sajak dikenal, sedangkan masyarakat Jepang cenderung terbalik, yakni berkarakter kurang terbuka dan tidak mudah akrab dengan orang yang baru saja dikenal. Perbedaan tersebut seringkali menimbulkan kesalahpahaman dalam berkomunikasi.

Dalam hal sosial, terdapat pula perbedaan masyarakat Indonesia dan Jepang. Salah satu contohnya adalah hal-hal yang berkaitan dengan privasi. Bagi masyarakat Jepang usia dan status pernikahan merupakan bagian dari privasi sedangkan bagi masyarakat Indonesia tidak.
Ketidakpahaman ranah privasi masyarakat Jepang oleh masyarakat Indonesia setidaknya akan menimbulkan kesalahpahaman dan hambatan dalam komunikasi.

Menurut KBBI (2005) privasi adalah kebebasan atau keleluasan pribadi. Dari segi sifatnya, Moore (2008) menyatakan bahwa privasi itu bersifat kultural dan kebenerannya relatif. Bisa jadi masuk ke dalam suatu ruangan tanpa mengetuk pintu merupakan sebuah pelanggaran privasi yang serius tapi belum tentu bagi yang lain. Hal itu bisa jadi disebabkan karena ada hal yang ingin dijaga baik berupa barang ataupun informasi oleh pemilik ruangan dan tidak ingin terganggu oleh kehadiran orang lain. Jika orang yang memasuki pintu tersebut mengetuk pintu, maka hal-hal yang dijaga oleh pemilik ruangan bisa dijaga terlebih dahulu. Bagi yang merasa tidak terganggu, 
bisa jadi tidak ada sesuatu yang dijaga oleh pemilik ruangan.

Selain itu, pendapat lain mengenai privasi dijelaskan oleh Mizutani, Dorsey, Moor (2004) yang menyatakan bahwa tidak ada kata dalam bahasa Jepang tradisional yang artinya sama persis dengan kata privacy dalam bahasa Inggris. Meskipun demikian, konsep privasi tetap ada dalam kehidupan masyarakat Jepang baik meliputi topik pembicaraan maupun dalam hal kebiasaan (custom). Dalam bahasa Jepang modern kata privacy diserap menjadi puraibashii yang ditulis dengan katakana yang artinya 'hal-hal yang berkaitan dengan kehidupan pribadi' (shiji), 'kehidupan pribadi' (shiseikatsu), atau 'rahasia' (himitsu). Dengan kata lain, privasi bisa didefinisikan sebagai hal-hal yang berkaitan barang, informasi, maupun tindakan yang di mana pemiliknya memiliki keleluasaan untuk menjaganya atau merahasiakannya maupun memberitahukannya kepada orang lain.

Pandangan terhadap privasi memengaruhi gaya dan strategi komunikasi berbahasa Jepang. Contohnya seperti yang telah dikemukakan di atas, masyarakat Jepang tidak suka jika ditanyai hal-hal yang berkaitan dengan usia dan status pernikahan. Menanyakan hal tersebut merupakan hal yang dianggap tidak sopan bagi masyarakat Jepang. Namun sayangnya, masih cukup banyak masyarakat Indonesia yang belum memahami bahwa hal tersebut masuk ke dalam ranah privasi masyarakat Jepang dan tidak baik untuk ditanyai.

Berdasarkan pengalaman, pengamatan, dan hasil wawancara penulis dengan penutur asli bahasa Jepang, ternyata ada hal-hal lain yang masuk ke dalam ranah privasi masyarakat Jepang yang memengaruhi komunikasi bahasa Jepang. Misalnya, masyarakat Jepang tidak suka ditanyai alamat rumah atau tempat tinggalnya karena bagi mereka itu bagian dari privasi dan ada perasaan curiga akan dikuntit jika alamat rumah mereka diketahui orang lain. Selain itu masih banyak lagi halhal yang masuk ke dalam ranah privasi masyarakat Jepang yang belum diketahui masyarakat Indonesia terutama pembelajar bahasa Jepang.

Pemahaman mengenai konsep privasi yang memengaruhi gaya dan strategi komunikasi bahasa Jepang sangat penting. Selain itu, kajian mengenai hal tersebut sangat perlu mengingat menurut hasil survey The Japan Foundation yang dilakukan dari tahun 2012 hingga tahun 2013, Indonesia menempati urutan kedua terbanyak di dunia dalam jumlah pembelajar bahasa Jepang. Jika pertumbuhan jumlah pembelajar bahasa Jepang di Indonesia sangat tinggi tanpa diiringi pemahaman budaya berbahasa Jepang, maka pembelajar bahasa Jepang di 
Indonesia akan sering menemui hambatan komunikasi dan proses komunikasi. Oleh karena itu, peneliti menilai perlu untuk meneliti tentang topik tersebut dengan mempertimbangkan aspek sosiolinguistik sebagai salah satu cara untuk mengurangi kesalahpahaman dan memperlancar proses komunikasi bahasa Jepang di kalangan pembelajar.

Berdasarkan latar belakang yang telah diuraikan sebelumnya, maka penelitian ini dilaksanakan dengan tujuan:

1. mengidentifikasi ranah privasi mahasiswa penutur bahasa Indonesia,

2. mengidentifikasi ranah privasi mahasiswa penutur bahasa Jepang,

3. mengidentifikasi kelompok yang dianggap boleh mengetahui privasi bagi mahasiswa penutur bahasa Indonesia,

4. mengidentifikasi kelompok yang dianggap boleh mengetahui privasi bagi mahasiswa penutur bahasa Jepang,

5. mengidentifikasi respons mahasiswa penutur asli bahasa Indonesia terhadap topik pembicaraan yang berkaitan dengan privasi,

6. mengidentifikasi respons mahasiswa penutur asli bahasa Jepang terhadap topik pembicaraan yang berkaitan dengan privasi,

7. mengidentifikasi persamaan dan perbedaan ranah privasi, kelompok yang dianggap boleh mengetahui privasi, dan respons mahasiswa penutur bahasa Indonesia dan mahasiswa penutur bahasa Jepang terhadap topik pembicaraan yang berkaitan dengan privasi.

\section{Metode Penelitian}

Tinjauan yang digunakan dalam penelitian ini adalah tinjauan sosiolinguistik interaksional yang diusulkan oleh Gumperz (2002), sedangkan metode analisis kontrastif yang digunakan adalah metode yang diusulkan oleh Mahsun (2005), yaitu metode padan ekstralingual. Metode padan ekstralingual merupakan salah satu metode menganalisis bahasa secara sinkronis. Mahsun (2007: 117) menguraikan bahwa kata padan bersinonim dengan kata banding; sehingga metode padan ekstralingual dimaknai sebagai sebuah kegiatan menghubung-bandingkan antara unsur-unsur yang berada dalam bahasa dengan unsur-unsur yang berada di luar bahasa, seperti hal-hal yang menyangkut makna, informasi, konteks, tuturan, dan lainlain. Metode ini dapat diterapkan untuk menganalisis unsur lingual yang terdapat dalam bahasa yang berbeda. Tujuan akhir dari membandingkan tersebut adalah menemukan persamaan pokok di antara data yang diperbandingkan tersebut (Mahsun, 2005: 259-260). 
Berikut tahapan-tahapan dalam menganalisis data:

a. mengumpulkan data (hasil angket) dari mahasiswa penutur asli bahasa Indonesia dan mahasiswa penutur asli bahasa Jepang

b. membuat kategori data: hal-hal yang masuk ke dalam ranah privasi mahasiswa penutur asli bahasa Indonesia dan mahasiswa penutur asli bahasa Jepang, kelompok yang boleh mengetahui dan tidak boleh mengetahui privasi mahasiswa penutur asli bahasa Indonesia dan mahasiswa penutur asli bahasa Jepang, alasan memberi tahu privasi dan alasan tidak memberi tahu privasi, respons penutur terhadap mitra tutur yang bertanya tentang privasi

c. menginput data sesuai kategori yang telah ditentukan

d. hasil analisis data mahasiswa penutur asli bahasa Indonesia dan mahasiswa penutur asli bahasa Jepang kemudian dibandingkan serta dikontrastifkan, lalu mencari titik-titik persamaan dan perbedaan di antara kedua penutur bahasa

e. menyusun laporan hasil analisis

Penelitian ini menggunakan teknik survei dengan menggunakan kuesioner yang bertujuan untuk mengukur eksistensi dan distribusi berbagai tingkah laku atau karakteristik secara alami, frekuensi kemunculan kejadian yang terjadi secara alamiah, dan hubungan serta besarnya hubungan-hubungan yang mungkin ada antara karakteristik, tingkah laku, kejadian atau fenomena yang menjadi perhatian peneliti (Alwasilah, 2009 : 151). Dalam penelitian ini survei dilakukan untuk mengamati dan mengetahui ranah privasi berdasarkan pemikiran mahasiswa penutur asli Indonesia dan mahasiswa penutur asli bahasa Jepang.

Jenis kuesioner atau angket yang digunakan adalah kuesioner dengan pertanyaan terbuka dan tertutup (open and cloesd questions). Pemilihan jenis kuesioner tersebut dikarenakan agar responden mudah memberikan jawaban dan memudahkan fokus pada pertanyaan untuk dijawab. Selain itu, peneliti menduga akan ada variasi jawaban lain dan berusaha mencari temuan baru dari setiap responden atau sampel.

Sumber data berasal dari hasil angket yang didistribusi kepada para sampel atau responden yang merupakan mahasiswa penutur asli bahasa Indonesia dan mahasiswa penutur asli bahasa Jepang. Sampel atau responden adalah mahasiswa penutur asli bahasa Indonesia yang sedang menempuh studi di perguruan tinggi di Indonesia dan mahasiswa penutur bahasa Jepang yang sedang menempuh studi di perguruan tinggi di Jepang. Jumlah kuesioner yang telah didistribusi kepada 
mahasiswa penutur asli bahasa Indonesia yang belum pernah ke Jepang sebanyak 127 orang, sedangkan kepada mahasiswa penutur asli bahasa Jepang telah didistribusi sebanyak 107 orang.

Penelitian dilaksanakan di dua tempat, yaitu Indonesia (Yogyakarta dan Bandung) dan Jepang (Mito dan Kyoto). Distribusi kuesioner di Indonesia dilakukan di Universitas Muhammadiyah Yogyakarta dan STBA YAPARI-ABA BANDUNG, sedangkan distribusi kuesioner di Jepang dilakukan di Ibaraki University (Prefektur Ibaraki) dan Ryukoku University (Kyoto). Lokasi-lokasi tersebut dipilih karena masing-masing kota tiap negara mewakili regional yang dinilai mempunyai karakteristik yang berbeda.

Data diperoleh melalui angket atau kuesioner yang didistribusikan di dua negara (Indonesia dan Jepang). Pertanyaan pada kuesioner terbagi ke dalam enam pertanyaan (klasifikasi) seperti berikut:

a. ruang lingkup (ranah) dianggap privasi bagi mahasiswa penutur asli bahasa Indonesia dan mahasiswa penutur asli bahasa Jepang,

b. kelompok yang dianggap boleh dan tidak boleh mengetahui privasi mahasiswa penutur bahasa Indonesia dan mahasiswa penutur asli bahasa Jepang, c. alasan mahasiswa penutur asli bahasa Indonesia dan bahasa Jepang memberitahu privasi,

d. alasan mahasiswa penutur asli bahasa Indonesia dan bahasa Jepang tidak memberitahu privasi,

e. respons mahasiswa penutur asli bahasa Indonesia dan bahasa Jepang saat ditanyai privasi oleh orang yang dianggap boleh mengetahuinya,

f. respons mahasiswa penutur asli bahasa Indonesia dan bahasa Jepang saat ditanyai privasi oleh orang yang dianggap tidak boleh mengetahuinya.

Setelah responden memberikan jawaban pada kuesioner, peneliti menghitung jumlah jawaban responden (data) pada setiap pertanyaan. Kemudian, baik data yang diperoleh dari responden penutur asli bahasa Indonesia dan penutur asli bahasa Jepang yang telah dikontraskan bisa diamati persamaan dan perbedaannya pada responden di Indonesia dan Jepang. Setelah mengetahui persamaan dan perbedaan pada mahasiswa penutur asli bahasa Indonesia dan mahasiswa penutur asli bahasa Jepang, peneliti dapat menarik simpulan.

\section{Hasil dan Pembahasan}

Untuk memudahkan analisis data, seperti yang telah dijelaskan di atas peneliti membagi himpunan data yang diperoleh ke 
dalam enam klasifikasi pertanyaan. Dalam

hal ranah privasi mahasiswa penutur asli bahasa Indonesia dan mahasiswa penutur asli bahasa Jepang, kita dapat mengetahui dengan melihat tabel di bawah ini.

Tabel 1.

Ruang Lingkup Privasi Mahasiswa Penutur Asli Bahasa Jepang dan Mahasiswa Penutur Asli Bahasa Indonesia

\begin{tabular}{|c|c|c|c|c|}
\hline \multirow[t]{2}{*}{ Urutan } & \multicolumn{2}{|c|}{ Mahasiswa Penutur Bahasa Jepang } & \multicolumn{2}{|c|}{ Mahasiswa Penutur Bahasa Indonesia } \\
\hline & Pilihan & Persentase $(\%)$ & Pilihan & Persentase $(\%)$ \\
\hline 1 & alamat rumah & 78,50 & kamar sendiri & 58,27 \\
\hline 2 & nilai / IPK & 77,57 & $\begin{array}{l}\text { penghasilan kerja } \\
\text { paruh waktu }\end{array}$ & 55,91 \\
\hline 3 & pekerjaan keluarga & 66,36 & mempunyai & 54,33 \\
\hline 4 & kamar sendiri & 65,42 & $\begin{array}{l}\text { kekasih atau tidak } \\
\text { pekerjaan keluarga }\end{array}$ & 48,82 \\
\hline 5 & $\begin{array}{c}\text { isi kantung/tempat } \\
\text { sampah }\end{array}$ & 62,62 & nilai / IPK & E-ISSN 48,03 \\
\hline 6 & $\begin{array}{c}\text { anggota keluarga } \\
\text { sendiri }\end{array}$ & 55,14 & alamat rumah & 26,77 \\
\hline 7 & tanggal lahir & 53,27 & tanggal lahir & 23,62 \\
\hline 8 & nama diri & 48,60 & $\begin{array}{c}\text { isi kantung/tempat } \\
\text { sampah }\end{array}$ & 23,62 \\
\hline 9 & $\begin{array}{c}\text { mempunyai } \\
\text { kekasih atau tidak }\end{array}$ & 43,93 & $\begin{array}{l}\text { anggota keluarga } \\
\text { sendiri }\end{array}$ & 17,32 \\
\hline 10 & $\begin{array}{c}\text { cara melewatkan } \\
\text { liburan }\end{array}$ & 35,51 & $\begin{array}{c}\text { pekerjaan paruh } \\
\text { waktu }\end{array}$ & 17,32 \\
\hline 11 & $\begin{array}{l}\text { penghasilan kerja } \\
\text { paruh waktu }\end{array}$ & 33,64 & hobi & 9,45 \\
\hline 12 & $\begin{array}{l}\text { pekerjaan paruh } \\
\text { waktu }\end{array}$ & 29,91 & nama diri & 8,66 \\
\hline 13 & hobi & 26,17 & $\begin{array}{c}\text { cara melewatkan } \\
\text { liburan }\end{array}$ & 8,66 \\
\hline
\end{tabular}

Jika melihat tabel di atas, alamat rumah (78,50\%), nilai/IPK (77,57\%), dan pekerjaan keluarga $(66,36 \%)$ dianggap tiga ruang lingkup privasi yang paling banyak dipilih mahasiswa penutur bahasa Jepang. Hasil tersebut sejalan dengan temuan yang menyatakan bahwa alamat rumah dianggap paling privasi $(95,6 \%)$. Sedangkan tiga ruang lingkup privasi yang paling banyak dipilih mahasiswa penutur bahasa Indonesia adalah kamar sendiri $(58,72 \%)$, penghasilan 
kerja paruh waktu $(55,91 \%)$ dan mempunyai kekasih atau tidak $(54,33 \%)$.

Tiga ruang lingkup privasi terendah yang dipilih mahasiswa penutur bahasa Jepang adalah penghasilan kerja paruh waktu $(33,64 \%)$, pekerjaan paruh waktu $(29,91 \%)$, dan hobi $(26,17 \%)$. Sedangkan tiga ruang lingkup privasi terendah yang dipilih mahasiswa penutur bahasa Indonesia adalah hobi $(9,45 \%)$, nama diri $(8,66 \%)$, dan cara melewatkan liburan $(8,66 \%)$.

Jika melihat persentase pada tabel di atas, meskipun kamar sendiri dipilih sebagai ruang lingkup privasi terbanyak oleh mahasiswa penutur bahasa Indonesia, persentasenya lebih kecil daripada ruang lingkup privasi mahasiswa penutur bahasa Jepang urutan kelima yaitu isi kantung/sampah (62,62\%). Dengan demikian, dapat disimpulkan bahwa mahasiswa penutur bahasa Indonesia lebih terbuka dalam hal privasi daripada mahasiswa penutur bahasa Jepang.

Tabel 2.

Kelompok yang Dianggap Boleh Mengetahui Privasi Penutur

\begin{tabular}{|c|c|c|c|c|}
\hline \multirow[t]{2}{*}{ Urutan } & \multicolumn{2}{|c|}{ Mahasiswa Penutur Bahasa Jepang } & \multicolumn{2}{|c|}{ Mahasiswa Penutur Bahasa Indonesia } \\
\hline & Pilihan & Persentase (\%) & ENG Pilihan $\mathrm{BAHAS}$ & entase (\%) \\
\hline 1 & keluarga sendiri & 92,52 & keluarga sendiri & 91,34 \\
\hline 2 & sahabat & 90,65 & sahabat & 89,76 \\
\hline 3 & kekasih & 80,37 & kekasih & 60,63 \\
\hline 4 & kerabat & 59,81 & kerabat & 49,61 \\
\hline 5 & senior dan junior & 44,86 & dosen pengampu & 27,56 \\
\hline 6 & dosen pengampu & 39,25 & $\begin{array}{l}\text { dosen yang tidak } \\
\text { mengampu }\end{array}$ & 12,60 \\
\hline 7 & kenalan & 20,56 & tetangga & 10,24 \\
\hline 8 & tetangga & 13,08 & senior dan junior & 10,24 \\
\hline 9 & $\begin{array}{l}\text { dosen yang tidak } \\
\text { mengampu }\end{array}$ & 11,21 & dll & 8,66 \\
\hline
\end{tabular}




\begin{tabular}{ccccc}
\hline \hline 10 & dll & 8 & kenalan & 7,09 \\
11 & $\begin{array}{c}\text { penjaga toko / } \\
\text { kantin }\end{array}$ & 6,54 & $\begin{array}{c}\text { penjaga toko / } \\
\text { kantin }\end{array}$ & 7,09 \\
\hline
\end{tabular}

Tabel 2 di atas menunjukkan bahwa tiga kelompok yang paling dianggap mahasiswa penutur bahasa Jepang boleh mengetahui privasinya adalah keluarga sendiri $(92,52 \%)$, sahabat $(90,65 \%)$, dan kekasih $(80,37 \%)$. Bisa dikatakan bahwa jika hubungan penutur dengan mitra tutur semakin dekat atau menjadi kelompok uchi (ingroup) maka semakin memungkinkan untuk menerima informasi pribadi penutur. Hal ini sejalan dengan Adams dkk (2009) bahwa penutur Jepang cenderung akan memberikan informasi pribadi kepada orang yang termasuk ke dalam kelompok uchi. Selain itu, sejalan dengan Maynard dalam Ogawa dan Gudykunst (1999) bahwa penutur
Jepang cenderung lebih dekat dengan kelompok uchi yang akrab. Sehingga dengan kedekatan tersebut memungkinkan untuk memperoleh informasi pribadi mitra tuturnya.

Sama dengan mahasiswa penutur bahasa Jepang, mahasiswa penutur bahasa Indonesia menempatkan keluarga sendiri (91,34\%), sahabat $(89,76 \%)$, dan kekasih $(60,63 \%)$ sebagai tiga kelompok yang paling dianggap boleh mengetahui privasi penutur. Artinya, jika penutur atau mitra tutur berada pada ingroup atau semakin dianggap ke dalam ingroup, cenderung semakin dianggap boleh mengetahui privasi.

Tabel 3.

Alasan Memberi Tahu Privasi

\begin{tabular}{|c|c|c|c|c|}
\hline \multirow[t]{2}{*}{ Urutan } & \multicolumn{2}{|c|}{ Mahasiswa Penutur Bahasa Jepang } & \multicolumn{2}{|c|}{ Mahasiswa Penutur Bahasa Indonesia } \\
\hline & Pilihan & Persentase $(\%)$ & Pilihan & Persentase $(\%)$ \\
\hline 1 & $\begin{array}{c}\text { karena Anda dan } \\
\text { mitra tutur saling } \\
\text { memiliki rasa saling } \\
\text { percaya }\end{array}$ & 87,85 & $\begin{array}{c}\text { karena Anda dan } \\
\text { mitra tutur saling } \\
\text { memiliki rasa saling } \\
\text { percaya }\end{array}$ & 73,23 \\
\hline 2 & $\begin{array}{c}\text { karena Anda sangat } \\
\text { mengenal mitra } \\
\text { tutur Anda }\end{array}$ & 63,55 & $\begin{array}{l}\text { karena Anda sangat } \\
\text { mengenal mitra } \\
\text { tutur Anda }\end{array}$ & 44,88 \\
\hline 3 & $\begin{array}{c}\text { karena mitra tutur } \\
\text { sangat mengenal } \\
\text { Anda }\end{array}$ & 54,21 & $\begin{array}{c}\text { karena mitra tutur } \\
\text { sangat mengenal } \\
\text { Anda }\end{array}$ & 40,16 \\
\hline
\end{tabular}


Sonda Sanjaya \& Yuriko Ando, Analisis Kontrastif Pandangan Mahasiswa Penutur Bahasa Indonesia dan Mahasiswa Penutur Bahasa Jepang Terhadap Privasi dalam Komunikasi:

Sebuah Tinjauan Sosiolinguistik

\begin{tabular}{|c|c|c|}
\hline 4 & $\begin{array}{c}\text { karena Anda } \\
\text { berpikir bahwa } \\
\text { Anda dan mitra } \\
\text { tutur ingin menjalin } \\
\text { kepercayaan }\end{array}$ & 37,38 \\
\hline 5 & $\begin{array}{l}\text { karena Anda } \\
\text { berpikir ingin } \\
\text { mengenal mitra } \\
\text { tutur }\end{array}$ & 18,69 \\
\hline 6 & $\begin{array}{l}\text { karena Anda } \\
\text { berpikir bahwa } \\
\text { mitra tutur ingin } \\
\text { mengenal Anda }\end{array}$ & 18,69 \\
\hline
\end{tabular}

Jika melihat Tabel 3 di atas, faktor yang membuat mahasiswa penutur asli bahasa Jepang bersedia menyampaikan informasi tentang privasinya adalah adanya hubungan yang disertai rasa saling percaya. Hal tersebut sejalan dengan pendapat Doi dalam Ogawa dan Gudykunst (1999) bahwa seseorang yang memiliki itikad baik dan memberikan rasa aman akan membentuk hubungan kepercayaan yang membuat mitra tutur merasa aman untuk menyampaikan hal

karena Anda
berpikir bahwa
Anda dan mitra
tutur ingin menjalin
kepercayaan
karena Anda
berpikir ingin
mengenal mitra
$\quad$ tutur
karena Anda
berpikir bahwa
mitra tutur ingin
mengenal Anda
gerkaitan dengan privasinya kepada
yang berkaitan dengan privasinya kepada mitra tutur dan penutur merasa aman karena mitra tutur akan menjaganya karena tidak akan mengancam (membocorkan privasi) penutur.

Sama dengan mahasiswa penutur bahasa Jepang, mahasiswa penutur bahasa Indonesia menjadikan hubungan kepercayaan sebagai faktor kesediaan untuk menyampaikan BAH informasi tentang privasinya.

Tabel 4.

Respons Saat Ditanyai Privasi oleh Orang yang Dianggap Boleh Mengetahuinya

\begin{tabular}{|c|c|c|c|c|}
\hline \multirow[t]{2}{*}{ Urutan } & \multicolumn{2}{|c|}{ Mahasiswa Penutur Bahasa Jepang } & \multicolumn{2}{|c|}{ Mahasiswa Penutur Bahasa Indonesia } \\
\hline & Pilihan & $\begin{array}{c}\text { Persentase } \\
(\%)\end{array}$ & Pilihan & $\begin{array}{l}\text { Persentase } \\
\quad(\%)\end{array}$ \\
\hline 1 & $\begin{array}{l}\text { menjawab sedikit demi } \\
\text { sedikit sembari melihat } \\
\text { situasi mitra tutur }\end{array}$ & 76,64 & $\begin{array}{l}\text { menjawab sedikit demi } \\
\text { sedikit sembari melihat } \\
\text { situasi mitra tutur }\end{array}$ & 87,40 \\
\hline 2 & $\begin{array}{c}\text { segera menjawab } \\
\text { semuanya }\end{array}$ & 10,28 & $\begin{array}{c}\text { segera menjawab } \\
\text { semuanya }\end{array}$ & 9,45 \\
\hline 3 & $\begin{array}{l}\text { sama sekali tidak } \\
\text { menjawab }\end{array}$ & 4,67 & berbohong & 0,79 \\
\hline
\end{tabular}




\begin{tabular}{|c|c|}
\hline berbohong & $\begin{array}{c}\text { sama sekali tidak } \\
\text { menjawab }\end{array}$ \\
\hline $\begin{array}{l}\text { Tabel } 4 \text { menunjukkan bahwa } \\
\text { mahasiswa penutur bahasa Jepang } \\
\text { adakalanya mempertimbangkan beberapa } \\
\text { hal atau situasi untuk membicarakan privasi } \\
\text { kepada orang yang dipercaya dan orang } \\
\text { yang dikenal. Hal tersebut disebabkan } \\
\text { mahasiswa penutur bahasa Jepang } \\
\text { cenderung tidak hanya menilai apakah mitra } \\
\text { tutur termasuk ke dalam kelompok uchi saja } \\
\text { tapi juga menilai tingkat intimasinya. } \\
\text { Disamping itu, penutur Jepang yang } \\
\text { cenderung menerapkan koletivisme akan } \\
\text { menggunakan high context communication } \\
\text { (Gudykunst dan Ting-Toomey dalam Ogawa } \\
\text { dan Gudykunst, 1999). Sehingga pertanyaan } \\
\text { yang berkaitan dengan privasi direspons } \\
\text { denan }\end{array}$ & $\begin{array}{l}\text { apakah mitra tutur sudah maşuk ke dalam } \\
\text { ingroup atau belum dan seberapa akrabkah } \\
\text { hubungan penutur dan mitra tutur. } \\
\text { Jika melihat tabel 4, respons yang } \\
\text { ditunjukkan mahasiswa penutur bahasa } \\
\text { Indonesia sama dengan mahasiswa penutur } \\
\text { bahasa Jepang. Namun, bagi mahasiswa } \\
\text { penutur bahasa Indonesia, pertimbangan } \\
\text { untuk menjawab pertanyaan mitra tutur yang } \\
\text { berkaitan dengan privasi cenderung lebih } \\
\text { banyak. Hal tersebut ditunjukkan persentase } \\
\text { jawaban "menjawab sedikit demi sedikit } \\
\text { sembari melihat situasi mitra tutur" } 5 \text { lebih } \\
\text { banyak ditemukan di mahasiswa penutur } \\
\text { bahasa Indonesia ( } 87,40 \% \text { ) daripada } \\
\text { mahasiswa penutur bahasa Jepang ( } 76,64 \%) \text {. }\end{array}$ \\
\hline
\end{tabular}

Tabel 5.

Respons Saat Ditanyai Privasi oleh Orang yang Dianggap Tidak Boleh Mengetahuinya \begin{tabular}{lll}
\hline Urutan & Mahasiswa Penutur Bahasa Jepang $\quad$ Mahasiswa Penutur Bahasa Indonesia
\end{tabular}

\begin{tabular}{|c|c|c|c|c|}
\hline & Pilihan & $\begin{array}{c}\text { Persentase } \\
(\%)\end{array}$ & Pilihan & $\begin{array}{c}\text { Persentase } \\
(\%)\end{array}$ \\
\hline 1 & $\begin{array}{c}\text { menjawab sedikit demi } \\
\text { sedikit sembari melihat } \\
\text { situasi mitra tutur }\end{array}$ & 36,45 & sama sekali tidak menjawab & 61,42 \\
\hline 2 & sama sekali tidak menjawab & 33,64 & $\begin{array}{l}\text { menjawab sedikit demi } \\
\text { sedikit sembari melihat } \\
\text { situasi mitra tutur }\end{array}$ & 16,54 \\
\hline 3 & berbohong & 20,56 & berbohong & 11,02 \\
\hline 4 & dll & 9,35 & dll & 10,24 \\
\hline
\end{tabular}


5 segera menjawab semuanya $\quad 0 \quad$ segera menjawab semuanya $\quad 0,79$

Tabel 5 di atas menunjukkan bahwa mahasiswa penutur bahasa Jepang masih mempertimbangkan beberapa hal atau situasi dalam penyampaian informasi mengenai privasi meskipun terhadap mitra tutur yang tidak memiliki hubungan kepercayaan atau mitra tutur yang tidak dikenal. Hal tersebut ditunjukan oleh persentase pada tabel di ataş. Meskipun persentasenya berbeda tipis dengan mahasiswa yang menjawab "sama sekali tidak menjawab" yang berjumlah $(33,64 \%)$, mahasiswa penutur bahasa Jepang yang menjawab "menjawab sedikit demi sedikit sembari melihat situasi mitra tutur" terbilang cukup banyak.

Sedangkan mahasiswa penutur bahasa Indonesia cenderung tegas untuk tidak sama sekali menyampaikan informasi mengenai privasi kepada orang yang tidak memiliki hubungan kepercayaan dan orang yang tidak dikenal. Hal ini ditunjukan persentase mahasiswa penutur bahasa Indonesia yang menjawab "sama sekali tidak menjawab" sebesar $61,42 \%$.

\section{Penutup}

Berdasarkan hasil analisis dapat disimpulkan bahwa tiga ruang lingkup yang paling dinilai privasi bagi mahasiswa penutur bahasa Indonesia adalah kamar sendiri, penghasilan kerja paruh waktu, dan status mempunyai kekasih atau tidak. Sedangkan bagi mahasiswa penutur bahasa Jepang, tiga ruang lingkup yang paling dinilai privasi adalah alamat rumah, nilai/IPK, dan pekerjaan keluarga. Kemudian, baik mahasiswa penutur bahasa Indonesia maupun mahasiswa penutur bahasa Jepang menempatkan keluarga sendiri, sahabat, dan kekasih sebagai tiga kelompok yang paling dianggap boleh mengetahui privasi penutur. 52 Terakhir, mahasiswa penutur bahasa Indonesia memutuskan akan membicarakan hal yang berkaitan dengan privasi atau tidak setelah memastikan apakah JE ada hubungan kepercayaan atau tidak dengan mitra tutur. Sedangkan mahasiswa penutur bahasa Jepang membicarakan privasi terhadap mitra tutur sembari mempertimbangkan apakah terdapat hubungan kepercayaan atau tidak pada mitra tutur. Dengan kata lain, penyampaian informasi privasi mahasiswa penutur bahasa Indonesia dilakukan setelah adanya konfirmasi mengenai hubungan dengan mitra tutur, sedangkan penyampaian informasi privasi mahasiswa penutur bahasa Jepang dilakukan di tengah proses pertimbangan mengenai hubungan dengan mitra tutur saat berkomunikasi. 


\section{Daftar Pustaka}

[1] Adams, A. A., Murata, K. and Orito, Y. (2009) The Japanese sense of information privacy. AI \& Society, 24 (4):324-341.

[2] Alwasilah, A. Chaedar. (2009). Pokoknya Kualitatif. Jakarta: Pustaka Jaya.

[3] Gumperz, John J. (2002). Studies in Interactional Sociolinguistics 1 Discourse Strategies. Cambridge: Cambridge University Press.

[4] Mahsun. (2007). Metode Penelitian Bahasa: tahapan strategi, metode, dan tekniknya. Jakarta: PT Raja Grafindo Persada.

[5] Mizutani, Masahiko dkk. (2004). The internet and Japanese conception of privacy. Ethics and Information Technology, 6: 121-128.

[6] Moore, Adam. (2008). Defining Privacy. Journal of Sociophilosophy, 39(3): 411-428.

[7] Ogawa, Naoto \& Gudykunst, William, B. Politeness Rules in Japan and the United States. Intercultural Communication Studies IX:1 19992000.

[8] Pusat Bahasa Departemen Pendidikan Nasional. (2005). Kamus Besar
Bahasa Indonesia. Jakarta: Balai Pustaka.

[9] Tamura, Takanori. (2005). Japanese feeling for privacy. In The 2nd AsiaPacific Computing and Philosophy Conference (pp. 88-93).

[10] The Japan Foundation. (2013). Survey Report on Japanese - Language Education Abroad. Tokyo: Kurosio. 